\title{
Влияние бактерий Bacillus subtilis в сочетании с сигнальными молекулами на содержание пролина и транскрипционную ак- тивность генов PR-белков в растениях картофеля при стрессе
}

( С Яруллина Л.Г. ${ }^{1}$, Заикина Е.А. ${ }^{1 *}$, Цветков В.О. ${ }^{2}$, Бурханова Г.Ф. ${ }^{1}$, Черепанова Е.А. ${ }^{1}$, Сорокань А.В. ${ }^{1}$, Марданшин И.С. ${ }^{3}$, Калацкая ж.H. ${ }^{4}$, Балюк Н.В. ${ }^{4}$

${ }^{1}$ Институт биохимии и генетики - обособленное структурное подразделение Уфримского фредерального исследовательского центра Российской академии наук Россия, Уфра, 450054, проспект Октября, 71.

${ }^{2}$ Федеральное государственное бюджетное образовательное учреждение высшего образования «Башкирский государственный университет»

Россия, Уфра, 450076, ул. Заки Валиди, 32.

${ }^{3}$ Башкирский научно-исследовательский институт сельского хозяйства - обособленное структурное подразделение Уфимского фредерального исследовательского центра Российской академии наук

Россия, Уфра, 450059, ул. Рихарда Зорге, 19.

${ }^{4}$ Государственное научное учреждение «Институт экспериментальной ботаники им. В. Ф. Купревича НАН Беларуси»

Беларусь, Минск, 220072, ул. Академическая, 27.

*Email: evisheva@yandex.ru

Исследовано влияние бактерий Bacillus subtilis в сочетании с салициловой (СК) и жасмоновой (ЖК) кислотами на содержание пролина и транскрипционную активность генов PR-белков в растениях картофеля при инфицировании Phytophthora infestans при недостатке влаги. Растения, выращенные из микроклубней сорта Ранняя Роза, опрыскивали суспензией $B$. subtilis и смесью бактерий с СК, ЖК, СК + ЖК. Через 3 дня после обработки растения инфицировали $P$. infestans и культивировали в условиях засухи. Выявлено снижение степени развития $P$. infestans на листьях при обработке $B$. subtilis в сочетании с СК и ЖК, которое коррелировало с повышением содержания пролина и уровнем экспрессии генов PR-белков.

Ключевые слова: Solanum tuberosum, Phytophthora infestans, Bacillus subtilis, пролин, экспрессия генов

В естественных условиях возделываемые культуры одновременно или последовательно подвергаются воздействию стрессовых фракторов различной природы. В этой связи наиболее перспективными представляются микробиологические подходы, основанные на использовании потенциала растений и почвенных микроорганизмов. Основой экологически чистых препаратов для защиты растений от биотических и абиотических стрессов являются стимулирующие рост растений бактерии (СРРБ) [1-2].

Среди абиотических фракторов, фрормирующих продуктивность растений, наиболее важным является наличие воды [3]. Рост и развитие картофеля, а также урожайность сильно зависят от влажности почвы. У картофеля эта зависимость выражена гораздо 
сильнее, чем у других видов сельскохозяйственных культур [4]. Известно, что ризобактерии могут значительно повысить засухоустойчивость растений [5-6].

Считается, что обработка растений СРРБ способствует развитию индуцированной системной устойчивости (ИСУ), опосредованной действием жасмоновой кислоты, маркером развития которой является индукция экспрессии защитного белка PR-6 [8]. Однако показано, что формирование устойчивости пшеницы к патогенам под действием бактерий рода Bacillus может развиваться и через салицилатный сигналинг по типу системной приобретенной устойчивости (СПУ), маркером развития которой служит индукция экспрессии защитного белка PR-1 [7].

Показано, что экзогенно применяемая салициловая кислота, помимо повышения устойчивости к патогенам, повышает устойчивость растений к ряду фризиологических стрессов [8], аналогичные данные были получены при обработке жасмонатом [9]. Таким образом, значительный интерес представляет выяснение механизмов индицирования устойчивости растений к патогенам и абиотическим стрессам под действием бактерий рода Bacillus в комплексе с сигнальными молекулами.

Цель работы - изучение влияния бактерий Bacillus subtilis в сочетании с СК и ЖК на содержание пролина и транскрипционную активность PR-генов при заражении Phytophthora infestans и засухе.

Материалы и методы. В опытах использовали растения картофеля Solanum tuberosum, выращенные из микроклубней восприимчивого сорта Ранняя роза. Клубни высаживали в емкости с грунтом (TerraVita). Растения выращивали на светоплощадке с фротопериодом 16 ч (освещенность 8000-10000 люкс) при температуре 20-22 ${ }^{\circ} \mathrm{C}$.

На 15-е сутки после прорастания растений, часть из них опрыскивали суспензией бактерий B. subtilis $26 Д$ (10 $10^{8}$ клеток / мл) и смесью бактерий с СК $\left(10^{-6} \mathrm{M}\right)$, ЖК $\left(10^{-7} \mathrm{M}\right)$ или СК $\left(10^{-6} \mathrm{M}\right)+$ ЖК $\left(10^{-7} \mathrm{M}\right)$. Контрольные опрыскивали 5 мл дистиллированной воды на 1 растение. На 3-и сутки после инокуляции B. subtilis 26Д растения опрыскивали 5 мл $1 \times 10^{5}$ спор / мл суспензии возбудителя фитофтороза P. infestans. В качестве контроля использовали растения, не инокулированные бактериями и не инфицированные фритофрторой.

Дефицит влаги создавали за счет сокращения полива. При появлении видимых симптомов засухи (увядание растений) через 7 дней после заражения $P$. infestans (влажность почвы при этом составляла $40 \% \pm 5$ от полной влагоемкости) [10] определяли содержание пролина в листьях. Часть листьев каждого варианта растений растирали в жидком азоте для выделения РНК.

О развитии болезни судили по проценту пораженной площади от общей площади листовой пластинки на 7-е сутки после заражения растений $P$. infestans. Листья фотографрировали, полученные изображения анализировали в компьютерной программе ImageJ (NIH, CШA).

Определение содержания пролина. Навеску растений заливали 2.5 мл стерильной дистиллированной воды. Пробирки помещали в водяную баню, которую затем доводили до кипения, после чего пробирки вынимали и охлаждали. Для приготовления реагента нингидрина 1.25 г нингидрина растворяли путем нагревания в 30 мл ледяной уксусной кислоты и 20 мл $6 \mathrm{M} \mathrm{H}_{3} \mathrm{PO}_{4}$, а затем охлаждали. Пробирки, содержащие 2 мл холодного образца, 2 мл реагента нингидрина и 2 мл ледяной уксусной кислоты, помещали на водяную баню и кипятили в течение часа, затем охлаждали. Оптическую плотность продуктов реакции измеряли на спектрофотометре при 522 нм. Концентрацию пролина определяли с использованием ранее полученной калибровочной кривой: 
навески пролина 10, 20, 30, 40, 50, 60 мкг растворяли в 2 мл 3\% сульфосалициловой кислоты, измеряли на Perkin Elmer LS 55 (США) при 522 нм, и строили кривую концентрации. Содержание пролина в образцах рассчитывали по формуле: $A=N \times V / P$, где $\mathrm{A}$ - концентрация пролина, $\mathrm{N}$ - значение по калибровочной кривой, $\mathrm{V}$ - объем разведения, мл, Р - масса образца, грамм.

Определение транскрипционной активности генов PR-белков. РНК выделяли из растений с помощью тризола (Molecular Research Center, Inc., США). Для получения кДНК на основе мРНК исследуемых образцов проводили реакцию обратной транскрипции с использованием обратной транскриптазы M-MuLV согласно протоколу поставщика. Анализ накопления транскриптов генов PR-1 (номер GenBank AY050221), PR-6 (номep GenBank JX683427) и PR-9 (номер GenBank M21334) проводили с помощью количественной ПЦР в реальном времени. кДНК разводили в пять раз и использовали непосредственно в качестве матрицы для количественной ПЦР (qPCR). Количественная ПЦР проводилась методом полимеразной цепной реакции в реальном времени с использованием N ', N'-диметил-N- (4 - ((E) - (3-метил-1,3-бензотиазол-2-илиден) метил) -1-френилхинолин-1-иум-2-ил) -N-пропилпропан-1,3-диамина (SYBR Greenl) (Synthol, Россия) на приборе CFX Connect Real-Time System (Bio-Rad, США). Программа qPCR: $50{ }^{\circ} \mathrm{C}$ в течение 2 мин; $95^{\circ} \mathrm{C}$ в течение 10 мин; 40 циклов при $95^{\circ} \mathrm{C}$ в течение 15 с и при $60{ }^{\circ} \mathrm{C}$ в течение 1 мин. Каждую количественную ПЦР проводили в трех повторностях. После заключительного цикла ПЦР был проведен анализ кривой плавления для определения специфики реакции (при $95^{\circ} \mathrm{C}$ в течение 15 секунд, $60{ }^{\circ} \mathrm{C}$ в течение 1 минуты и $95^{\circ} \mathrm{C}$ в течение 15 секунд). Эфрфективность каждой пары праймеров была определена с использованием серии 10-кратных разведений кДНК для надежного определения кратных изменений. Изменения транскрипционной активности гена (оценка количества копий мРНК для каждого гена) проводили относительно эталонного гена St_act («ген домашнего хозяйства», актин, номер GenBank X55749) с использованием программного обеспечения «CFX Connect Real-Time System» (Bio-Rad, США).

Статистическая обработка. Эксперименты включали 5 биологических повторностей для биохимических показателей и 15 - для транскрипционной активности. На гистограммах показаны выборочные средние и их 95\%-ные доверительные интервалы. Различия исследуемых параметров анализировали с помощью теста Краскела - Уоллиса. Достоверно различающиеся значения обозначены на гистограммах разными буквами.

Результаты и их обсуждение. Влияние бактерий Bacillus subtilis и сигнальных молекул на инфицирование растений картофеля $\boldsymbol{P}$. infestans в условиях засухи. Сравнительный анализ степени пораженности фритофторозом листьев восприимчивого сорта картофреля при недостатке влаги выявил различия в скорости роста оомицета $P$. infestans в вариантах с инокуляцией бактериями и сигнальными молекулами (рис. 1). Так, в отсутствие обработки степень пораженности составила $64 \%$, предварительная обработка B. subtilis, в том числе в сочетании с СК и ЖК, значительно снижала пораженность листьев. Предобработка $B$. subtilis в сочетании с ЖК оказала наиболее эфрфективное защитное действие (рис. 1). Ранее нами было показано, что обработка ЖК и B. subtilis 26Д снижают развитие $P$. infestans на клубнях картофеля [11].

Особенностью эндофитных бактерий является их способность воздействовать на рост растений непосредственно за счет синтеза различных метаболитов гормональной и сигнальной природы, таких как ауксины, цитокинины, гиббереллины, абсцизовая, салициловая и жасмоновая кислоты [12], индуцирующих неспецифическую активацию защитных механизмов растений. Системная индуцированная устойчивость, вызываемая СРРБ, эффрективна против грибов, оомицетов, бактерий, вирусов и насекомыхвредителей. 


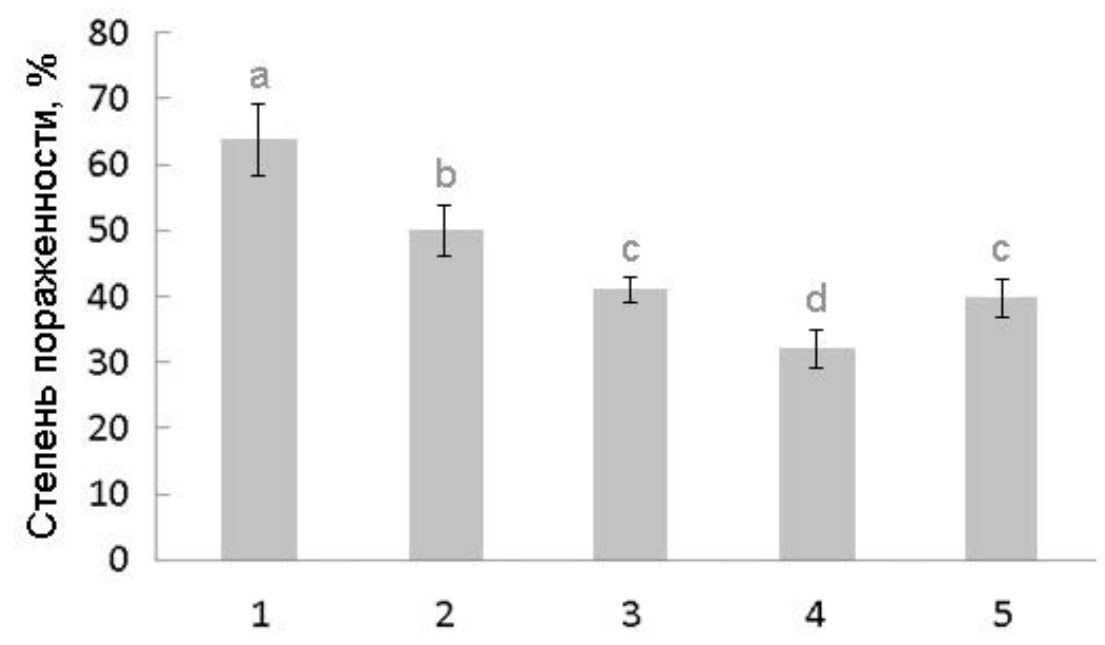

Рисунок 1. Влияние обработки бактериями B. subtilis в сочетании с СК и ЖК на пораженность листьев картофреля фритофрторозом в условиях засухи. 1 - контроль; 2 - B. subtilis; 3 - B. subtilis + СК; 4 - B. subtilis + ЖК; 5 - B. subtilis + СК + ЖК. Достоверно различающиеся значения обозначены на гистограммах разными буквами.

Влияние бактерий Bacillus subtilis и сигнальных молекул на содержание пролина. Исследования выявили антистрессовый эффеект обработки бактериями B. subtilis $26 Д$ на растениях картофеля в условиях засухи. Так, в растениях, обработанных $B$. subtilis, уровень пролина в листьях незараженных растений увеличивался в несколько раз (рис. 2). Сочетание бактерий с ЖК, но особенно с СК, снижало стимулирующее действие $B$. subtilis на уровень пролина в неинфицированных растениях. Однако, в ва-

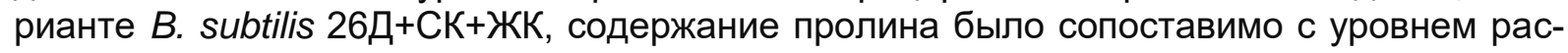
тений, обработанных бактериями. Сходная тенденция влияния сочетания бактерий и сигнальных молекул на уровень пролина сохранялась и в инфицированных растениях (рис. 2).

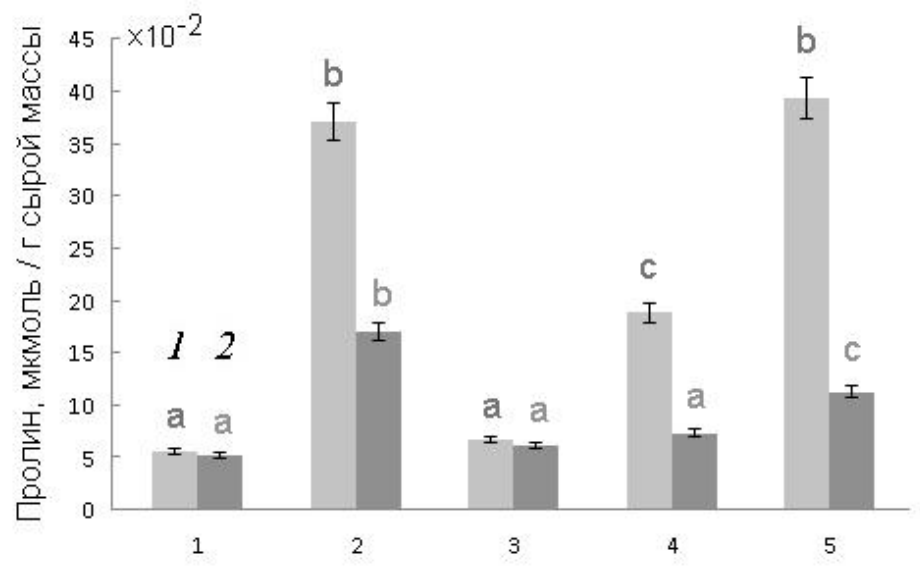

Рисунок 2. Влияние обработки бактериями B. subtilis в сочетании с СК и ЖК на содержание пролина в листьях картофеля при заражении $P$. infestans в условиях засухи. 1 контроль; 2 - B. subtilis; 3 - B. subtilis + СК; 4 - B. subtilis + ЖК; $5-$ B. subtilis + СК + ЖК. 1 - незараженные, 2 - зараженные $P$. infestans растения. Достоверно различающиеся значения обозначены на гистограммах разными буквами. 
Известно, что пролин играет роль осмопротектора при засухе, накапливаясь в цитозоле растительных клеток [13]. Защитный эффект пролина обусловлен его участием в стабилизации мембран, структуры белковых молекул и снижении уровня АФК [13].

Влияние бактерий Bacillus subtilis и сигнальных молекул на транскрипционную активность генов PR-белков в растениях картофеля при заражении P. infestans в условиях засухи. Системная устойчивость растений к болезням, являющаяся неспецифической, основана на экспрессии многих защитных генов. Как видно на рис. 3, инфрицирование и обработка $B$. subtilis, особенно в сочетании с сигнальными молекулами, стимулировали накопление транскриптов генов PR-1, PR-6 и PR-9 в растениях картофреля. Так ген PR-1 наиболее интенсивно экспрессировался у растений, обработанных бактериями в сочетании с СК. Обработка B. subtilis в сочетании с ЖК приводила к значительному увеличению уровня транскрипции гена PR-6 у неинфицированных и инфицированных растений по сравнению с контролем.

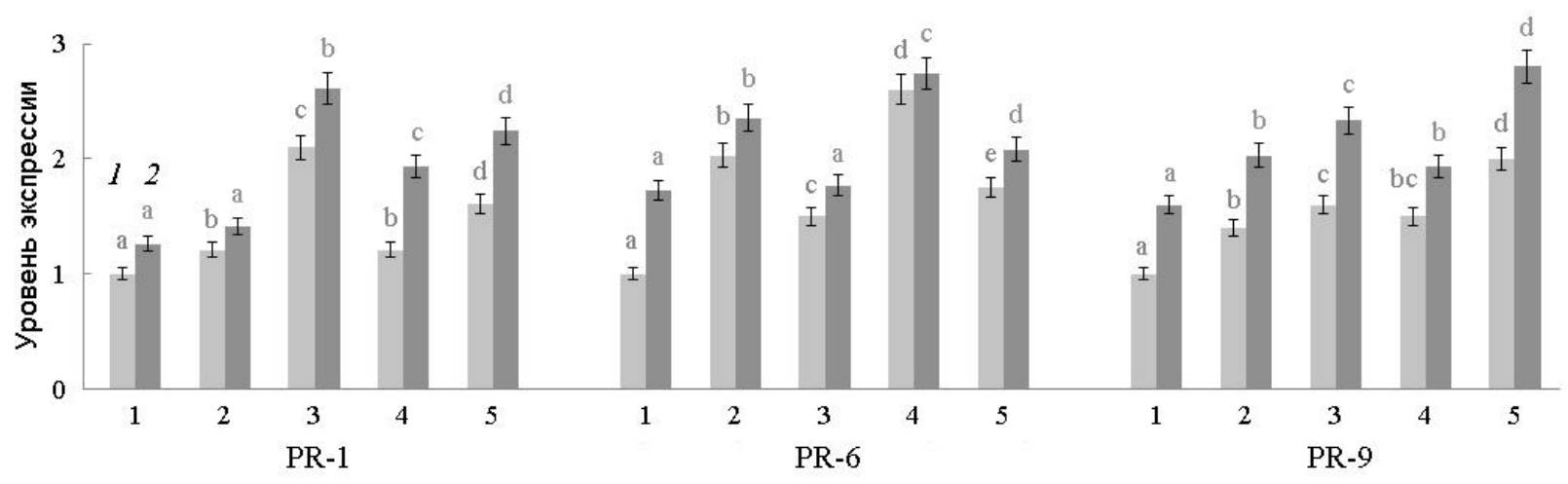

Рисунок 3. Влияние обработки бактериями B. subtilis в сочетании с СК и ЖК на уровень экспрессии генов защитных белков. 1 - контроль; 2 - B. subtilis; 3 - B. subtilis + CK; 4 B. subtilis + ЖК; 5 - B. subtilis + СК + ЖК. 1 - незараженные, 2 - зараженные $P$. infestans растения. Достоверно различающиеся значения обозначены на гистограммах разными буквами.

Следует обратить внимание, что обработка бактериями B. subtilis в отсутствие сигнальных молекул оказывала значительное влияние на повышение уровня экспрессии PR-1 и PR-6 у незараженных растений в условиях засухи. Комбинация бактерий с СК и ЖК в данном случае имела, как правило, меньший, а в некоторых случаях даже отрицательный эффрект, например, экспрессия PR-6 снижалась в присутствии СК. У инфицированных растений, обработанных бактериями в сочетании с СК или ЖК, значительно повышалась экспрессия PR-белков. В неинфицированных растениях экспрессия PR-9 увеличивалась при обработке $B$. subtilis как в отсутствие, так и в комбинации с CK или ЖК, но комбинированный эффрект СК и ЖК вызывал большее увеличение экспрессии PR-9. Ранее было показано, что ЖК может нейтрализовать способность B. subtilis 26Д стимулировать транскрипционную активность гена PR-9 в условиях нормальной влажности [12]. Супрессивный эфрфект совместной обработки B. subtilis $26 Д+$ ЖК выражался в снижении транскрипции генов PR-2, PR-3 и PR-9 в растениях пшеницы по сравнению с растениями, обработанными только B. subtilis 26Д или ЖК. Следовательно, совместное влияние засухи и заражения патогеном приводит к дополнительным 
изменениям транскрипционной активности PR-генов растений по сравнению с инфицированными растениями, выращенными в нормальных условиях. Полученные данные могут быть использованы для разработки биопрепаратов, обладающих комплексным защитным эффректом на растения в стрессовых условиях.

Работа выполнялась при фринансовой поддержке РФФИ и БРФФИ в рамках научного проекта № 20-516-00005, на оборудовании ЦКП “Биомика" и УНУ “Кодинк".

\section{Литература}

1. Maksimov I.V., Veselova S.V., Nuzhnaya T.V., Sarvarova E.R., Khairullin R.M. Plant growth-promoting bacteria in regulation of plant resistance to stress factors // Russian Journal of Plant Physiology. 2015. V. 62. P. 715-726.

2. Verma P., Yadav A.N., Kumar V., Singh D.P., Saxena A.K. Beneficial plant-microbes interactions: biodiversity of microbes from diverse extreme environments and its impact for crop improvement // Plant-Microbe Interactions in Agro-Ecological Perspectives / Eds. Singh D.P., Singh H.B., Prabha R. Singapore: Springer, 2017. P. 543-580.

3. Vurukonda S.S.K.P., Vardharajula S., Shrivastava M., SkZ A. Enhancement of drought stress tolerance in crops by plant growth promoting rhizobacteria // Microbiological Research. 2016. V. 184. P. 13-24.

4. Burton W.G. Challenges for stress physiology in potato // American Potato Journal. 1981. V. 58. P. 3-14.

5. Marasco R., Rolli E., Ettoumi B., Vigani G., Mapelli F., Borin S., Abou-Hadid A.F., ElBehairy U.A., Sorlini C., Cherif A., Zocchi G., Daffonchio D. A drought resistance-promoting microbiome is selected by root system under desert farming // PLoS One. 2012. V. 7. No. 10. Article e48479.

6. Coleman-Derr D., Tringe S.G. Building the crops of tomorrow: advantages of symbiontbased approaches to improving abiotic stress tolerance // Front Microbiol. 2014. V. 5. P. 283.

7. Veselova S.V., Nuzhnaya T.V., Maksimov I.V. Jasmonic acid: biosynthesis, functions and role in plant development // Series Plant Science Research and Practices / Ed. Morrison L. USA: Nova Science Publishers, 2015. P. 33-66.

8. Burkhanova G.F., Veselova S.V., Sorokan' A.V., Blagova D.K., Nuzhnaya T.V., Maksimov I.V. Strains of Bacillus ssp. regulate wheat resistance to Septoria nodorum Berk..// Appl Biochem Microbiol. 2017. V. 53. No. 3. P. 346-352.

9. Hayat Q., Hayat S., Irfan M., Ahmad A. Effect of exogenous salicylic acid under changing environment: A review // Environmental and Experimental Botany. 2010. V. 68. P. 14-25.

10. Chanda B., Xia Y., Mandal M.K., Sekine K.T., Gao Q.M., Selote D. Glycerol-3phosphate, a critical mobile inducer of systemic immunity in plants // Nat Genet. 2011. V. 43. P. 421-427.

11. Lastochkina O.V., Aliniaeifard S., Seifikalhor M., Yuldashev R., Pusenkova L., Garipova S. Plant growth-promoting bacteria: biotic strategy to cope with abiotic stresses in wheat // Wheat Production in Changing Environments. Responses, Adaptation and Tolerance / Eds. Hasanuzzaman M., Nahar K., Hossain A. Singapore: Springer, 2019. P. 579-6. 
12. Maksimov I.V., Abizgildina P.P., Sorokan A.V., Burkhanova G.F. Regulation of peroxidase activity under the influence of signaling molecules and Bacillus subtilis 26D in potato plants infected with Phytophthora infestans // Applied Biochemistry and Microbiology. 2014. V. 50. No. 2. P. 173-178.

13. Pireivatloum J., Qasimov N., Maralian H. Effect of soil water stress on yield and proline content of four wheat lines. // Afr J Biotech. 2010. V. 9. P. 36-40.

\section{Influence of Bacillus subtilis bacteria in combination with signaling molecules on pro- line content and transcriptional activity of PR-protein genes in potato plants under stress}

Yarullina L.G. ${ }^{1}$, Zaikina E.A. ${ }^{1 *}$, Tsvetkov V.O. ${ }^{2}$, Burkhanova G.F. ${ }^{1}$, Cherepanova E. ${ }^{1}$, Sorokan A.V. ${ }^{1}$, Mardanshin I.S. ${ }^{3}$, Kalatskaya J.N. ${ }^{4}$, Balyuk N.V. ${ }^{4}$

${ }^{1}$ FGBUN Institute of Biochemistry and Genetics UFIC RAS, 71, Pr. Oktyabrya, Ufa, 450054, Russia

${ }^{2}$ FSBEI HE Bashkir State University, 32, Zaki Validi str., Ufa, 450076, Russia

${ }^{3}$ FGBUN Bashkir Research Institute of Agriculture, 450059 Russia, Ufa, Zorge str., 19

${ }^{4}$ GNU Institute of Experimental Botany named after V. F. Kuprevich NAS of Belarus, 27, Akademicheskaya str., Minsk, 220072, Republic of Belarus

*Email: evisheva@yandex.ru

The effect of Bacillus subtilis bacteria in combination with salicylic (SA) and jasmonic (JA) acids on the proline content and transcriptional activity of PR-protein genes in potato plants during Phytophthora infestans infection and drought was studied. Plants grown from microtubers of the Rannyaya Rosa cultivar were sprayed with a suspension of $B$. subtilis and a mixture of bacteria with SA, JA, SA + JA. 3 days after treatment, the plants were infected with $P$. infestans and cultivated under drought conditions. A decrease in the degree of $P$. infestans development on leaves was revealed upon treatment with $B$. subtilis in combination with SA and JA, which correlated with an increase in the proline content and the level of expression of PR-protein genes.

Key words: Solanum tuberosum, Phytophthora infestans, Bacillus subtilis, proline, gene expression 